\title{
ZRÓŻNICOWANIE POSTAW WOBEC KONSULTACJI SPOLECZNYCH W POLSCE JAKO PRZEJAW REGIONALNEGO ZRÓŻNICOWANIA TRADYCJI OBYWATELSKICH ${ }^{1}$
}

\section{Streszczenie}

Artykuł podejmuje już nienową, ale wciąż interesującą tematykę wpływu różnic regionalnych na postawy i zachowania obywatelskie, wychodząc z założenia, że bardzo istotnym czynnikiem różnicującym tradycje obywatelskie na obszarze Polski jest uprzednia przynależność obszaru do danego mocarstwa zaborczego. Osobny obszar stanowią ziemie przyłączone do Polski w 1945 r., które w okresie zaborów bez wyjątku należały do Prus.

W opracowaniu wskaźnikiem omawianego zróżnicowania są głównie postawy i zachowania wobec konsultacji społecznych. Do przygotowania opracowania wykorzystano wyniki badania partycypacji obywatelskiej w Polsce zrealizowanego w ramach programu „Decydujmy razem”, finansowanego przez Unię Europejską, udostępnionego dzięki uprzejmości Fundacji Instytutu Spraw Publicznych w Warszawie.

Słowa kluczowe: rozbiory Polski, konsultacje społeczne, tradycje obywatelskie, partycypacja obywatelska, partycypacja społeczna

* Dr, Instytut Filozofii, Socjologii i Dziennikarstwa, Zakład Teorii Socjologicznej i Metodologii Badań Społecznych; e-mail: wns@univ.gda.pl

1 Dane przytaczane w artykule zostały udostępnione dzięki uprzejmości Fundacji Instytutu Spraw Publicznych w Warszawie. Pochodzą z badania przeprowadzonego w ramach projektu „Decydujmy razem. Wzmocnienie mechanizmów partycypacyjnych w kreowaniu i wdrażaniu polityk publicznych oraz podejmowaniu polityk publicznych", współfinansowanego przez Unię Europejską z Europejskiego Funduszu Społecznego. Obliczeń na potrzeby artykułu dokonał Michał Kotnarowski, któremu składam podziękowania. 


\section{WSTĘP}

Temat zróżnicowania tradycji czy też etosu różnych regionów w obrębie tego samego państwa i ich wpływ ogólnie na jakość funkcjonowania instytucji obywatelskich, władz lokalnych i regionalnych podejmowano już od czasów Alexisa de Tocqueville'a. W XX w. inspiracją dla wielu badaczy tego zagadnienia była praca Edwarda Banfielda [1967]. Po 1989 r. powstało szereg opracowań traktujących o czynnikach warunkujących erozję i trwanie tradycji obywatelskich w polskich regionach [Gorzelak i Jałowiecki 1998; Zarycki 1997, 2007; Bartkowski 2003; Żukowski 2004; Swaniewicz, Herbst, Lackowska; Mielczarek 2009; Jasiewicz 2009; Grosfeld i Zhuravskaya 2015 i in.].

W prezentowanych niżej badaniach oparto się na założeniu przyjętym za Robertem Putnamem w jego klasycznej już pracy o polskim tytule Demokracja $w$ działaniu [Putnam 1995], że natężenie i charakter aktywności obywatelskiej zależą od pewnych cech wynikających z przynależności danej społeczności lokalnej do regionu o określonej tradycji zachowań w sferze publicznej i politycznej, zachowań obywatelskich. Region historyczny jest nośnikiem określonej wiązki cech kulturowych, które wywierają wpływ na poziom i charakter partycypacji obywatelskiej. Przyjmuję za Tomaszem Kaźmierczakiem, że partycypacja obywatelska to wszelkie działanie zbiorowe zmierzające do poprawy ogólnego dobra, dobrostanu danej społeczności przyporządkowanej do określonego obszaru. Kaźmierczak na podstawie ustaleń autorów brytyjskich zalicza do niej zarówno partycypację publiczną, inaczej zwaną wertykalna, jak i znacznie mniej jasno zdefiniowaną partycypację społeczną, zwaną też horyzontalną [Brodie i in. 2009, za: Kaźmierczak 2011: 83].

Partycypacja wertykalna obejmuje przejawy zaangażowania jednostek w działania struktur i instytucji demokratycznych od poziomu lokalnego (gminy i jednostki pomocnicze gmin) do poziomu ogólnopaństwowego. Używa się w tym kontekście także określenia „rządzenie partycypacyjne” (participatory governance) [Kaźmierczak 2011: 84].

Partycypacja horyzontalna natomiast dotyczy udziału jednostek w działaniach zbiorowych podejmowanych w społeczności (społecznościach), do której one przynależą, w której żyją na co dzień, obecności w procesie powstawania i funkcjonowania (lokalnych) grup obywatelskich i organizacji pozarządowych [por. Kaźmierczak 2011: 83].

Konsultacje społeczne to proces, w którym przedstawiciele władz (tu: szczebla gminnego lub miejskiego) starają się poznać opinie, stanowiska, wartości osób $\mathrm{i}$ instytucji, których dotkną konsekwencje wprowadzanych przez te władze zmian 
(inwestycji, planów zagospodarowania przestrzennego itp.) [Konsultacje 2016]. W ciagu ostatnich kilkunastu lat forma partycypacji publicznej uległa dużemu rozpowszechnieniu. $Z$ drugiej strony, z racji dużego stopnia ogólności procedur ją określających jej charakter, funkcje i przebieg określone są w dużym stopniu przez społecznie wytworzone przekonania [por. Berger, Luckmann 2010] na temat tego, czym jest partycypacja obywateli w sprawowaniu lokalnej władzy.

Główną tezą artykułu jest założenie, że zainteresowanie konsultacjami społecznymi i udział w nich wynika z przynależności gminy, w której mieszkali respondenci, do obszaru jednego z trzech państw zaborczych, pod którego rządami ukształtowały się: określony stosunek do życia publicznego, ,kultura polityczna” [Almond i Verba 1963] czy też lepsza lub gorsza „kultura obywatelska” [Wnuk-Lipiński 2005]. Do osobnej kategorii zaliczyć należy mieszkańców Ziem Zachodnich i Północnych, którzy swoją kulturę polityczną budowali w oparciu o zróżnicowane doświadczenia przodków pochodzących z różnych regionów przedwojennej Polski.

\section{RÓŻNE TRADYCJE OBYWATELSKIE POLSKICH REGIONÓW}

W okresie 1795-1918, a szczególnie od połowy XIX wieku, procesy przechodzenia od społeczeństwa agrarnego do przemysłowego uległy zasadniczemu przyspieszeniu. Ukształtowały się zręby instytucjonalne, infrastrukturalne, gospodarcze i społeczne kształtującego się społeczeństwa nowoczesnego, jakkolwiek kultura polityczna i zakres swobód obywatelskich w każdym z zaborów znacząco się różniły. Zakres swobody społecznej, narodowościowej, politycznej na obszarze zaboru austriackiego po 1867 r. był nieporównanie większy niż w pozostałych dwóch zaborach ${ }^{2}$ [por. Zarycki 1997: 185-187]. Istniejące tu nierówności i zacofanie, w połączeniu z względną swobodą działalności polityczno-społecznej zaowocowały silnym rozwojem ruchów politycznych i innych organizacji: charytatywnych, spółdzielczych, religijnych, stawiających sobie za cel walkę o poprawę losu warstw ekonomicznie i społecznie upośledzonych; szczególne znaczenie miał ruch ludowy [Bartkowski 2003: 161-162]. Można więc założyć, że to region o relatywnie najlepiej rozwiniętych tradycjach obywatelskich.

Polityka zaborcy pruskiego, później niemieckiego, prowadziła do względnie szybkiego rozwoju stosunków gospodarczych w stronę gospodarki kapitalistycz-

2 Ogromna liczba urzędników, nauczycieli, polityków, artystów późniejszej II Rzeczypospolitej mogła wykształcić się i zdobyć kwalifikacje dzięki autonomii politycznej, społecznej i kulturalnej tzw. Galicji [Grzybowski 1959]. 
nej. Choć napotykał on na poważne przeszkody polityczno-administracyjne, to jednak relatywna zamożność i stabilne ramy prawne stworzyły warunki do rozwoju niezależnego ruchu gospodarczego i społecznego spółdzielczości i stowarzyszeń, a w konsekwencji - organizacji politycznej. Działalność społeczna przenikała się tu z gospodarczą i przez to nie była może tak „obywatelska” jak w Galicji, lecz z pewnością pozostawiła po sobie tradycje silniejsze niż w zaborze rosyjskim [Bartkowski 2003: 138-146].

Ziemie Zachodnie i Północne (dalej ZZiP) to obszar zamieszkany przez zbiorowości „postmigracyjne”. Większość badaczy akcentuje niski kapitał społeczny i niską oddolną aktywność na tych obszarach, co wynika ze słabszego poczucia zakorzenienia i związku z lokalną społecznością, a po części także $\mathrm{z}$ występowania w większym nasileniu problemów stanowiących skutek upadku gospodarki centralnie sterowanej i słabości elit społeczno-kulturalnych [Tujdowski 2008: 28-35].

Oczywiście uwarunkowania rozwoju, trwania i zaniku lokalnych i regionalnych tradycji obywatelskich bywają złożone. Sprzyjająca polityka władz, swoboda samorządu itd. mogą nie być warunkiem wystarczającym, ani nawet koniecznym, rozwoju obywatelskiej aktywności, na co wskazuje np. społecznikowska tradycja inteligencka byłego zaboru rosyjskiego [por. Zarycki 1997: 189]. W tym ostatnim istniały bardzo ograniczone ramy prawne dla rozwoju organizacji spółdzielczych i tym podobnych, które pojawiły się głównie po wydarzeniach rewolucyjnych 1905-1907 r. Niezależne życie społeczne przed 1915 r. toczyło się tu w opozycji do władz lub ewentualnie za ograniczonym przyzwoleniem w przypadku działalności niezwiązanej z polityką lub kulturą polską. Dlatego też szczególne znaczenie miał w tym zaborze etos inteligencki, którego elementem było oddziaływanie na warstwy słabiej edukowane. Tradycje obywatelskie mają w nim więc bardziej elitystyczny i ekskluzywny charakter (do dziś oddziałujący na życie polityczne), ale są słabiej zakorzenione lokalnie [por Zarycki 2014: 45-68].

Prezentowany wywód poparty jest materiałem empirycznym zebranym podczas badania przeprowadzonego w ramach projektu „Decydujmy razem” pod koniec 2011 r. w 193 gminach (w tym siedmiu dzielnicach Warszawy). Operatem losowania była lista gmin zawierająca dane pochodzące z GUS ${ }^{3}$. W doborze gmin zastosowano schemat doboru warstwowego. Zakładano dobór z 64 warstw

3 Wraz z 18 dzielnicami Warszawy, które na potrzeby losowania potraktowano jako dodatkowe 18 gmin. 
pochodzących ze skrzyżowania województwa i 4 typów gmin (wiejska, miejsko-wiejska, miejska-mniejsza, miejska-większa ${ }^{4}$ ).

W niniejszym artykule korzystam z opracowania wyników wywiadów z mieszkańcami tychże gmin, których zebrano dokładnie 1000. Były to obszerne wywiady kwestionariuszowe realizowane w bezpośrednim kontakcie przeszkolonego ankietera z badanym, metodą CAPI. Dobór mieszkańców w badaniu miał charakter losowy: korzystając z bazy adresowej Poczty Polskiej, przeprowadzono losowanie adresów w badanych 193 gminach (w liczbie proporcjonalnej do wielkości gmin w próbie), a w gospodarstwie domowym posłużono się metodą „ostatnich urodzin”. Ubytki w próbie uzupełniano z rezerwowej listy adresowej [por. Kotnarowski 2012: 14-19; tam także dokładny opis metodologii badania] ${ }^{5}$.

Badania Instytutu Spraw Publicznych służyły celom badawczo-wdrożeniowym projektu „Decydujmy razem”, czyli, najogólniej rzecz biorąc, dokonaniu diagnozy partycypacji obywatelskiej w Polsce. Pierwotnie nie zakładano dokonania analizy materiału w ujęciu uwzględniającym podział kraju na dzielnice pozaborowe i Ziemie Zachodnie i Północne. Podział taki dokonany został a posteriori w jednym $\mathrm{z}$ artykułów powstałych $\mathrm{w}$ ramach projektu [Peisert, Kotnarowski 2012]. Wyodrębniono gminy znajdujące się w trzech dzielnicach zaborowych oraz tzw. Ziemie Zachodnie i Północne i przeprowadzono analizę przejawów partycypacji obywatelskiej w każdej z tak wyróżnionych czterech „dzielnic”, głównie na podstawie wywiadów z włodarzami ${ }^{6}$ i sekretarzami gmin.

Krytyczna analiza tego podziału skłoniła mnie do wyłączenia spośród wyróżnionych kategorii regionalnych pewnych mniejszych całości, które w sposób ewidentny odbiegały od charakterystyki regionu jako, ogólnie rzecz ujmując, „dzielnicy pozaborowej” (lub ZZiP), były więc dla nich „atypowe”. Celem poszukiwania takiego podziału było uchwycenie charakterystycznego dla danego

4 Rozgraniczenie na mniejszą i większą przeprowadzono według wartości mediany liczby mieszkańców gmin miejskich w próbie.

5 W celu dokonania doboru mieszkańców dla każdej gminy wylosowanej w poprzednim etapie określono dokładną liczbę wywiadów do przeprowadzania, proporcjonalną do wielkości gminy. Konstruując próbę mieszkańców, nałożono wymóg minimum dwóch wywiadów w gminie. Cel ten osiagnięto przez zmniejszenie liczby wywiadów w największych gminach. Zgodnie $\mathrm{z}$ ustaleniami zawartymi w literaturze statystycznej kluczowe znaczenie dla precyzji oszacowań modeli wielopoziomowych ma duża liczba obserwacji na drugim poziomie (tu - liczba gmin). Minimalna liczba obserwacji na drugim poziomie wynosi od 50 do 100 . W omawianym badaniu liczba ta wyniosła 193. Według literatury przedmiotu liczba obserwacji w poszczególnych grupach (tutaj-gminach) nie powinna być mniejsza niż dwie obserwacje, co zostało zapewnione [por. Mass \& Hox 2005; Clarke \& Wheaton 2007; Bell et all 2010, za: Kotnarowski 2012].

6 Ogólna nazwa wybieralnych włodarzy gmin: wójtów, burmistrzów miast i dzielnic Warszawy, prezydentów miast. 
regionu „pozaborowego" habitusu zachowań obywatelskich. Innymi słowy, celem jest tu wyłączenie miast i gmin stanowiących wyjątek dla swojego „zaboru”, których nie uwzględnia się, gdy wyróżnione zostają tylko wyżej wymienione cztery „dzielnice” Polski - tak jak zaproponowali Jałowiecki i Gorzelak [1998] czy Zarycki [1997] - zróżnicowane ze względu na rodzaj tradycji obywatelskiej. Do uproszeń (zakłoceń) tych zaliczam:

1. Przyporządkowanie do kategorii Ziem Zachodnich i Północnych terenów zamieszkanych przez ludność rodzimą autochtoniczną, tj. np. Ślązaków i ,zasiedziałych” Niemców.

2. Zaliczenie do ogólnej kategorii zaboru rosyjskiego miast o silnych tradycjach robotniczych i przemyśle wywodzącym się z XIX w.

3. Brak wyodrębnienia Warszawy jako wciąż jedynej w Polsce metropolii o charakterze kosmopolitycznym, której nie sposób przyporządkować do zaboru rosyjskiego.

Wypada uzasadnić pokrótce proponowane wyłączenia.

Ad. 1. Pewnych społeczności tzw. Ziem Zachodnich i Północnych nie sposób zaliczyć do tzw. zbiorowości postmigracyjnych, charakteryzujących się m.in. większą otwartością, elastycznością i egalitaryzmem struktury społecznej, ale też mniejszym zakorzenieniem i słabszym poczuciem wspólnoty terytorialnej [Sakson 1996, za: Zarycki 1997: 191-192]. Najbardziej charakterystyczny pod tym względem jest Śląsk Opolski [Zarycki 1997: 205-210]. Wobec braku bardziej jednoznacznych kryteriów uznałem, że w przypadku Śląska zasadne będzie wyodrębnienie byłego obszaru plebiscytu z 1921 r. z części, która nie została przyłączona do Polski. Na obszarze tym przeważa ludność polska, zaś zamieszkującej go ludności niemieckiej nie dosięgły wysiedlenia po $1945 \mathrm{r}$. Za takim rozwiązaniem przemawia także efekt tzw. inwersji etnicznej [por. Zarycki 1997: 205]. Na innych terenach pogranicza etnicznego polsko-niemieckiego, które leżały poza terenem II RP, doszło do daleko idącej wymiany ludności.

Ad. 2. Zabór rosyjski był w drugiej połowie XIX w. terenem względnie intensywnego rozwoju przemysłu, stymulowanego bliskością ogromnego rynku zbytu w Rosji. Dlatego tam właśnie pojawiły się pierwsze większe okręgi robotniczo-przemysłowe [Nietyksza 1986: 335-347], poza samą Warszawą - włókiennicze w Łodzi oraz bardziej zróżnicowane w Zagłębiu Dąbrowskim; miały one jednak charakter wyspowy. W okresie bezpośrednio poprzedzającym wybuch I wojny światowej ruchy polityczne i społeczne istniejące $\mathrm{w}$ tych ośrodkach przemysłowych znacznie rozwinęły swą bazę, ujawniając siłę m.in. w wystąpieniach $1905 \mathrm{r}$. [Tych 1990: 15-44], ponadto licznie pojawiały się tam stowarzyszenia spółdziel-

7 Dla uproszenia „,zabór” jest tu rozumiany jako jeden z trzech zaborów lub ZZiP. 
cze, przede wszystkim pożyczkowe i spożywców [Księga polskiej spółdzielczości 2004: 29-31]. Dlatego też wyróżniłem nieliczną wprawdzie, ale odrębną kategorię „strefy robotniczo-przemysłowej” byłego zaboru rosyjskiego, zaliczając do niej Łódź i Zagłębie Dąbrowskie, a także Białystok - „Manchester Północy”. Te miasta robotnicze, znane z sympatii do SLD w latach dziewięćdziesiątych, jaskrawo odróżniały się od „narodowo-katolickich” lokalnych społeczności miejscowości centralnej i wschodniej Polski - byłego zaboru rosyjskiego, co nie było szerzej komentowane we wcześniejszych analizach ilościowych [Zarycki 1997: 190, Gorzelak i Jałowiecki 1998] $]^{8}$.

Ad. 3. Warszawa to jedyne miasto w Polsce wykazujące cechy kosmopolitycznej metropolii, zasiedlone po wojnie w ogromnej mierze od nowa, przez ludność o zróżnicowanym pochodzeniu regionalnym i społecznym. Z tego też powodu analizy dotyczące zachowań obywatelskich warszawiaków powinny być wyodrębnione $\mathrm{z}$ analiz mieszkańców byłego zaboru rosyjskiego.

Podsumowując, w analizowanym dalej materiale wyłączyłem mieszkańców badanych gmin, którzy zamieszkiwali jeden z następujących obszarów:

- mieszkańcy tej części obszaru plebiscytowego Górnego Śląska z 1921 r., która nie znalazła się w II RP - 50 osób,

- mieszkańcy dzielnic Warszawy - 71 osób,

- mieszkańcy typowych miast „robotniczych” byłego zaboru rosyjskiego (Łódź i Zawiercie) $)^{9}-53$ osoby.

Dane dotyczące tych zbiorowości zostały przedstawione w tabelach, nie omawiam ich jednak dalej ze względu na niskie liczebności i większy wpływ zmiennych niezależnych.

Pozostałych 826 respondentów pozostawiłem w 4 dotychczasowych kategoriach, według zamieszkania w jednym z ,regionów”, czy raczej „stref” różnych tradycji obywatelskich. Byli to:

- mieszkańcy Ziem Zachodnich i Północnych (osiedleńczych) - 228,

- mieszkańcy ziem byłego zaboru pruskiego oraz województwa śląskiego w II RP - 211,

- mieszkańcy ziem byłego zaboru austriackiego - 126,

- mieszkańcy terenów byłego zaboru rosyjskiego - 261 .

$8 \quad \mathrm{Z}$ drugiej jednak strony mocno podkreślano silne zróżnicowanie mieszkańców Śląska i Zagłębia, z których to drugie wyróżniało się zdecydowanymi sympatiami lewicowymi [Zarycki 1997: 203-205; Bartkowski 2003].

9 Zawiercie to miasto z XIX-wiecznymi jeszcze tradycjami socjalistycznymi, a w okresie międzywojennym - silny ośrodek komunistów, w którym pierwsze szlify aktywności politycznej zdobywał Władysław Gomułka. 


\section{DZIEDZICTWO ZABORÓW A KANDYDOWANIE W WYBORACH}

Jedną z istotnych miar partycypacji wertykalnej (poza samą frekwencją wyborcza) jest korzystanie z biernego prawa wyborczego. Zanim przejdziemy do głównego tematu opracowania - konsultacji społecznych, warto porównać w tym zakresie wyróżnione regiony. Odpowiedzi na pytanie kwestionariuszowe dotyczące partycypacji wertykalnej: „Czy kiedykolwiek kandydowałeś w wyborach na sołtysa, radnego dowolnego szczebla, wójta, starostę (burmistrza, prezydenta miasta)?", potwierdzają słuszność przyjętej hipotezy. W tym zakresie najwięcej odpowiedzi twierdzących znów padło na terenie byłego państwa Habsburgów, gdzie w takich wyborach startował co dziesiąty respondent. Na drugim miejscu znaleźli się mieszkańcy zaboru rosyjskiego z wynikiem 7,7\% twierdzących odpowiedzi, a niewiele dalej mieszkańcy ziem zagarniętych ongiś przez Prusy $-6,3 \%$. Najrzadziej tak rozumianą aktywność przejawiali osadnicy i ich potomkowie na ZZiP (2,7\%, czyli bez mała co czterdziesty badany).

\section{ZRÓŻNICOWANIE REGIONALNE KONSULTACJI SPOLECZNYCH}

Coraz istotniejszą formą wertykalnej partycypacji bezpośredniej jest udział w konsultacjach społecznych. W prezentowanym badaniu zapytano o fakt udziału w nim w ciagu 12 miesięcy poprzedzających badanie. W konsultacjach uczestniczyło 18,3\% badanych mieszkańców Galicji, 14,8\% mieszkańców byłego zaboru pruskiego, 10,3\% mieszkańców zaboru rosyjskiego oraz 7,8\% mieszkańców ZZiP (tabela 1)

W niektórych miejscowościach duże zainteresowanie mogły budzić na przykład konsultacje związane z różnorodnymi inwestycjami infrastrukturalnymi, których nie było w innych miejscowościach.

Zapytano więc, czy respondenci brali udział w konsultacjach na temat kultury. Założono, że skłonności do udziału w konsultacjach w tym zakresie nie różnicują znaczące czynniki strukturalne, a czynione w tej sferze inwestycje są zazwyczaj skromne i nieczęste. Jak pokazano w tabeli 2 , również pod tym względem przodowali mieszkańcy zaboru pruskiego $(5,6 \%)$ i austriackiego $(4,1 \%)$, za którymi znaleźli się mieszkańcy ZZiP $(2,1 \%)$ i dawnego zaboru rosyjskiego $(1,1 \%)$.

Kolejnym badanym przejawem wertykalnej partycypacji obywatelskiej były deklaracje gotowości (zamiaru) udziału w różnych formach konsultacji społecznych. Różne formy tego zamierzonego (a nie: zrealizowanego) udziału świadczą o większym lub mniejszym zaangażowaniu w konsultacje. 


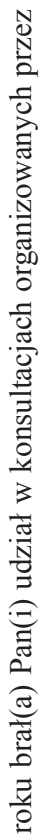

E

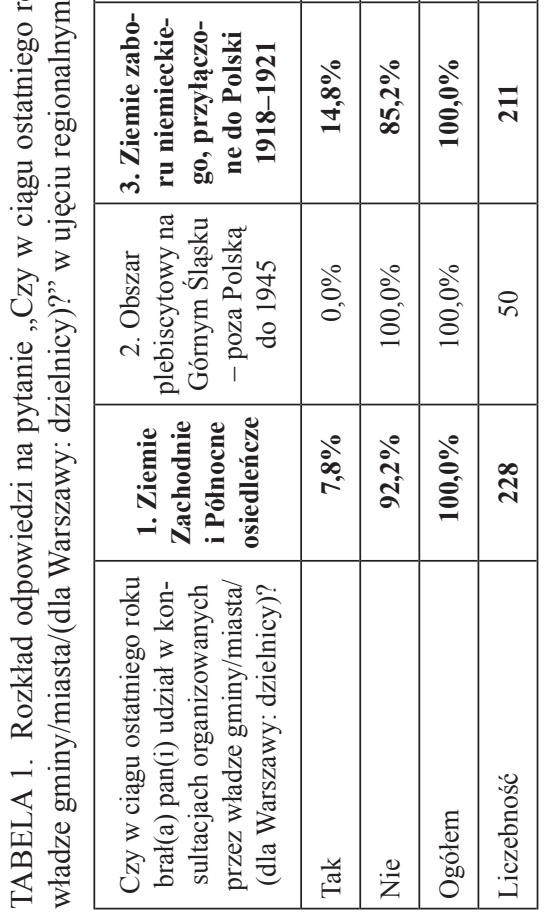

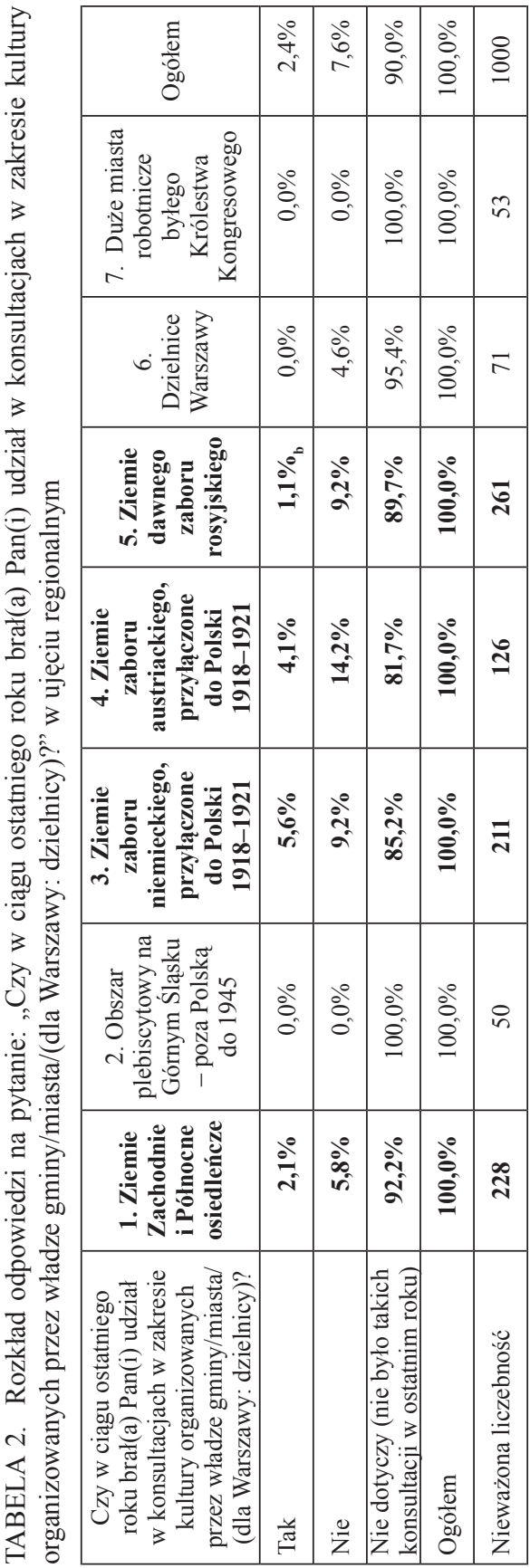


Badani proszeni byli o wskazanie do 3 form udziału w konsultacjach, spośród 8 przedstawionych, które gotowi byliby aktualnie podjać. Dokonałem więc ex post podziału tych form na: pośrednie, półpośrednie i bezpośrednie. Do pierwszych z nich zaliczyłem: zamiar przekazywania opinii na pośrednictwem Internetu, zgodę na udział w ewentualnym badaniu ankietowym oraz gotowość składania podpisów deklarujących poparcie lub brak poparcia dla ewentualnych rozwiązań proponowanych przez władze gminy/miasta/dzielnicy. Formy te łączy pozytywny stosunek do udziału w konsultacjach społecznych, ale wyłącznie poprzez działania pasywne, nie wymagające opuszczania mieszkania.

Do form półpośrednich zaliczyłem gotowość do podjęcia nieco większego zaangażowania (czasowego i merytorycznego) w przekazywanie swoich opinii władzom. W dalszym ciągu jednak była to aktywność nie zakładająca bezpośredniego kontaktu z radnymi, urzędnikami czy włodarzem gminy. Za jej przykłady uznałem gotowość składania swoich uwag w specjalnym punkcie konsultacyjnym (jakie funkcjonują okresowo lub stale w wielu już miastach) oraz gotowość przekazywania pisemnych opinii na wskazany adres lub do wskazanego miejsca (wysłanie ich pocztą lub złożenie osobiście).

Wreszcie do form bezpośrednich, które zakładają bezpośredni kontakt z radnymi, urzędnikami lub włodarzem miasta, zaliczyłem gotowość udziału w otwartych dla mieszkańców sesjach plenarnych rady gminy/miasta lub posiedzeniach odpowiednich komisji rady gminy/miasta. Włączyłem do nich także gotowość udziału w zebraniach przedstawicieli władz z mieszkańcami. Były to więc formy wymagające największej aktywności: po pierwsze, śledzenia zapowiedzi takich wydarzeń, po drugie, osobistego w nich udziału. Do tej kategorii zaliczyłem także gotowość przekazywania opinii za pośrednictwem radnych. Ta trzecia forma w wielu małych miejscowościach oznacza najczęściej bezpośredni kontakt $\mathrm{z}$ radnym. A więc zdobycie (lub uprzednie posiadanie) danych kontaktowych radnego i ich wykorzystanie do bezpośredniego kontaktu telefonicznego czy e-mailowego celem przekazania uwag. Formy te różnicuje także spodziewany poziom anonimowości, z jakiej jest gotów zrezygnować obywatel w celu wyrażenia swojej opinii (bezpośrednia - najmniej anonimowa, pośrednia - najbardziej anonimowa). Stanowi to swego rodzaju miarę odwagi cywilnej. Podkreślmy raz jeszcze, pytanie dotyczyło deklarowanych w przyszłości form udziału w konsultacjach, a nie faktu udziału w nich.

W tabeli 3 zostało to przedstawione w następujący sposób: jeżeli choć jedna forma miała charakter bezpośredni, to respondent zaliczany był do grupy gotowych do udziału bezpośredniego. 


\begin{tabular}{|c|c|c|c|c|c|c|c|c|c|c|c|c|c|}
\hline 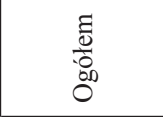 & $\frac{\dot{b}_{0}^{0}}{\vec{\gamma}}$ & $\begin{array}{l}\stackrel{0}{\infty} \\
\overbrace{}^{n}\end{array}$ & 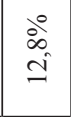 & $\begin{array}{l}\stackrel{\circ}{\partial} \\
\vec{\nabla}\end{array}$ & $\mid \begin{array}{l}0 \\
8 \\
8 \\
8 \\
-\end{array}$ & $\stackrel{8}{\varrho}$ & \multirow{9}{*}{ 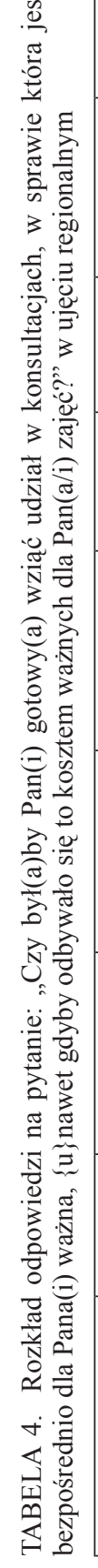 } & $\begin{array}{l}\text { ह } \\
\frac{0}{0} \\
0 \\
0\end{array}$ & & $\mid \begin{array}{c}0 \\
i n \\
\infty \\
\infty \\
n\end{array}$ & $\begin{array}{l}\stackrel{0}{\mathrm{i}} \\
\stackrel{0}{0}\end{array}$ & & 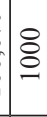 \\
\hline 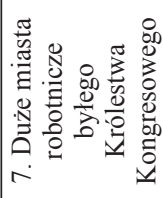 & $\begin{array}{l}\text { oे } \\
\text { bे }\end{array}$ & 字 & $\begin{array}{l}8 \\
0 \\
0\end{array}$ & $\begin{array}{l}\stackrel{0}{i} \\
\dot{0} \\
0\end{array}$ & $\mid \begin{array}{l}0 \\
8 \\
0 \\
8 \\
0\end{array}$ & $\tilde{n}$ & & 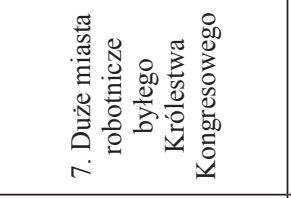 & 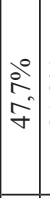 & $\left|\begin{array}{c}0 \\
\infty \\
-1 \\
\vec{N}\end{array}\right|$ & $\begin{array}{l}\text { 尺ें } \\
\text { ñ } \\
\text { in }\end{array}$ & & $n$ \\
\hline 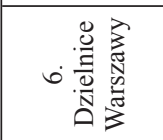 & $\begin{array}{l}\stackrel{\circ}{i} \\
\dot{f}\end{array}$ & $\begin{array}{l}0 \\
\dot{m} \\
\dot{m}\end{array}$ & $\stackrel{\stackrel{\circ}{\beth}}{=}$ & $\begin{array}{l}0 \\
\infty \\
\infty \\
\dot{+}\end{array}$ & $\mid \begin{array}{l}0 \\
8 \\
8 \\
8 \\
8\end{array}$ & $\nabla$ & & 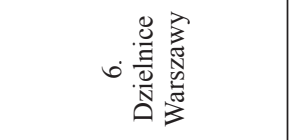 & $\left|\begin{array}{c}0 \\
\infty \\
\infty \\
\\
\mid\end{array}\right|$ & 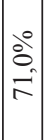 & $\frac{\partial^{\circ}}{m}$ & $\begin{array}{l}0 \\
8 \\
8 \\
8 \\
8\end{array}$ & $\nabla$ \\
\hline 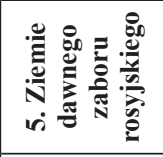 & $\begin{array}{l}\stackrel{0}{0} \\
\text { लें } \\
\text { ले }\end{array}$ & $\frac{\partial}{a}$ & $\begin{array}{l}\stackrel{0}{\circ} \\
\stackrel{0}{=}\end{array}$ & $\begin{array}{l}\dot{b}^{0} \\
\text { in } \\
\text { ñ }\end{array}$ & $\mid \begin{array}{l}\stackrel{0}{\circ} \\
\stackrel{0}{\circ} \\
\hat{\theta}\end{array}$ & $\bar{\vdots}$ & & 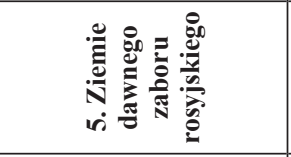 & $\mid \begin{array}{l}0 \\
\text { తి } \\
\mid\end{array}$ & 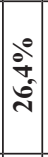 & 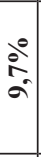 & $\begin{array}{l}\stackrel{0}{8} \\
\stackrel{\theta}{\theta} \\
\hat{\theta}\end{array}$ & $\bar{\sim}$ \\
\hline 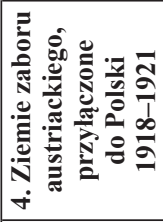 & 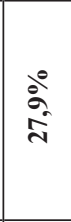 & 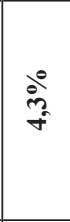 & $\begin{array}{l}\stackrel{0}{2} \\
\text { in } \\
\stackrel{2}{2}\end{array}$ & $\begin{array}{c}\stackrel{0}{0} \\
\text { in } \\
\text { în }\end{array}$ & 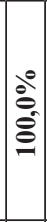 & $\stackrel{0}{\beth}$ & & 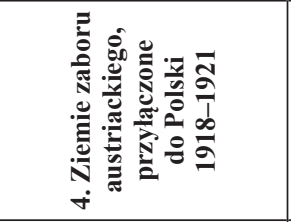 & 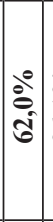 & 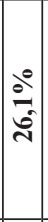 & $\begin{array}{l}\stackrel{0}{\circ} \\
\stackrel{\sigma}{=}\end{array}$ & $\begin{array}{l}0 \\
\stackrel{8}{\theta} \\
\hat{\theta} \\
\hat{\theta}\end{array}$ & $\stackrel{2}{\mathcal{2}}$ \\
\hline 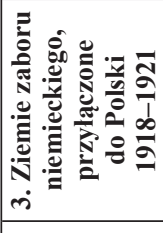 & $\begin{array}{l}\stackrel{0}{\circ} \\
\stackrel{2}{+}\end{array}$ & $\begin{array}{l}\stackrel{0}{0} \\
\stackrel{0}{0}\end{array}$ & $\begin{array}{l}\stackrel{0}{0} \\
\stackrel{y}{\beth}\end{array}$ & $\frac{\partial}{\frac{\rho}{q}}$ & $\mid \begin{array}{l}\stackrel{0}{\circ} \\
\stackrel{8}{0} \\
\hat{\theta}\end{array}$ & $\bar{\sim}$ & & 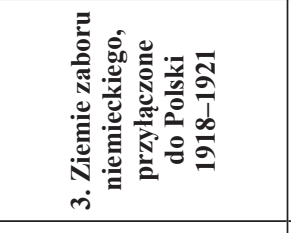 & $\mid \begin{array}{c}0 \\
m^{\circ} \\
\sigma^{2}\end{array}$ & 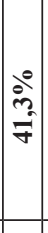 & $\begin{array}{l}\partial^{\circ} \\
\sigma^{\prime} \\
\sigma^{\prime}\end{array}$ & $\begin{array}{l}\stackrel{\circ}{\circ} \\
\stackrel{\theta}{8} \\
\hat{\theta}\end{array}$ & $\bar{N}$ \\
\hline 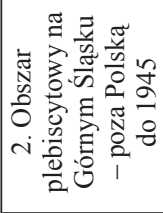 & $\begin{array}{l}\delta^{\circ} \\
\text { in }\end{array}$ & $\begin{array}{l}\text { in } \\
\text { in }\end{array}$ & $\begin{array}{l}\stackrel{0}{0} \\
\text { î } \\
\text { î }\end{array}$ & 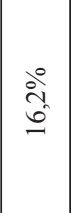 & $\mid \begin{array}{l}0 \\
8 \\
8 \\
8 \\
8\end{array}$ & in & & 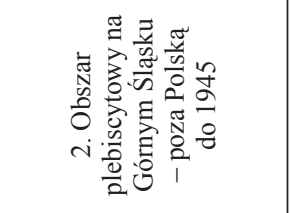 & $\left|\begin{array}{c}0 \\
\dot{b} \\
\infty \\
m \\
m\end{array}\right|$ & 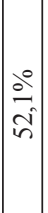 & ڤें & & in \\
\hline 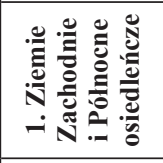 & $\frac{\stackrel{0}{i}}{\stackrel{\infty}{+}}$ & $\begin{array}{l}\stackrel{0}{r} \\
\stackrel{5}{n}\end{array}$ & $\begin{array}{l}\text { bे } \\
\text { aे }\end{array}$ & $\begin{array}{l}\stackrel{\circ}{\circ} \\
\dot{e} \\
\dot{m}\end{array}$ & $\mid \begin{array}{l}\stackrel{0}{0} \\
\stackrel{\theta}{8} \\
\hat{\theta}\end{array}$ & $\underset{\mathbb{N}}{\infty}$ & & 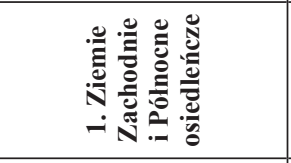 & $\mid \begin{array}{l}0 \\
2 \\
6 \\
6\end{array}$ & 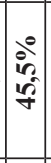 & $\begin{array}{l}\stackrel{0}{0} \\
\dot{b}_{0} \\
\infty\end{array}$ & & 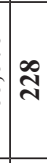 \\
\hline 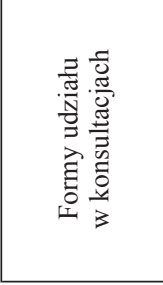 & 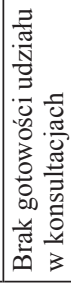 & 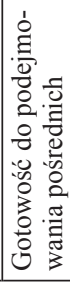 & 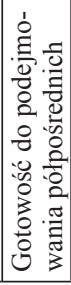 & 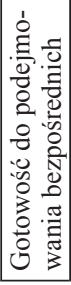 & 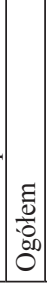 & 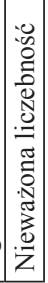 & & 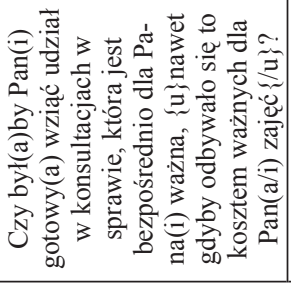 & & $: \frac{0}{z}$ & 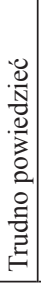 & $\begin{array}{l}\text { E्ञ } \\
\frac{1}{0} \\
0 \\
0\end{array}$ & 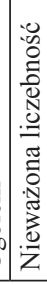 \\
\hline
\end{tabular}


Jeżeli takiej brakowało, to zaliczany był do grupy gotowych do udziału półpośredniego, pod warunkiem, że wskazywała na to choć jedna forma. Jeżeli były to wyłącznie formy pośrednie, wówczas zaliczany był to tej grupy. Zestawienie obejmuje także tych, którzy w ogóle nie wyrażali potrzeby udziału w konsultacjach.

Spośród ogółu badanych brak gotowości udziału w konsultacjach w jakiejkolwiek formie wyraziło $41,6 \%$ badanych. Gotowych do przekazywania opinii wyłącznie w formie pośredniej było 3,8\%, w formach najwyżej półpośrednich - 12,8\%, zaś w formie bezpośredniej - aż 41,9\% spośród ogółu badanych.

W tym przypadku tradycja Galicji znów pokazała swoją trwałość. Niechętnych do udziału w konsultacjach było zaledwie $27,9 \%$ badanych. Bardziej zaskakujące jest to, że tylko niewielu więcej niechętnych było na terenie byłego zaboru rosyjskiego - 32,7\%, a w pozostałych dwóch regionach historycznych gotowość do udziału w konsultacjach była zbliżona i wahała się w granicach 47,3-48,8\%.

Gotowość udziału w uznanych przeze mnie za najbardziej aktywne (a więc obywatelskie) formach konsultacji społecznych wyraziło 52,3\% badanych z Galicji i 52,6\% badanych z byłego zaboru rosyjskiego. Rzadsza była gotowość do udziału w takich formach konsultacji wśród mieszkańców byłego zaboru rosyjskiego - 40,1\%, a najrzadsza na terenie ZZiP - 34\%. Dla ogółu badanych 1000 respondentów wynosiła ona $41,9 \%$.

Mieszkańcy Ziem Zachodnich i Północnych najrzadziej biorą udział w konsultacjach i najrzadziej wyrażają zamiar udziału w nich w przyszłości. Przeciwnie niż mieszkańcy Galicji - wysokiemu udziałowi towarzyszy w ich przypadku równie konsekwentny zamiar udziału w przyszłości. To, co zaskakujące i wyłamujące się z przyjętej hipotezy, to nadspodziewanie częste deklaracje udziału w konsultacjach społecznych w przyszłości wśród mieszkańców byłego zaboru rosyjskiego, przy niskim udziale $\mathrm{w}$ tych dotychczasowych. W dalszej części podjęta zostanie próba zrekonstruowania różnić w charakterze motywacji do udziału w konsultacjach

\section{EGOISTYCZNE A WSPÓLNOTOWE MOTYWACJE DO UDZIALU W KONSULTACJACH}

Motywacje do udziału w konsultacjach mogą być bardzo zróżnicowane. Czasami wynikają z obywatelskiego zaangażowania, czasami zaś z bardzo egoistycznych pobudek - potrzeby ochrony własnych interesów, według znanej zasady NIMBY lub BANANA ${ }^{10}$. Dlatego też, aby „odsiać” wpływ tego zjawiska, w omawianym

10 Akronimy oznaczające odpowiednio: NIMBY - ,not in my back yard” (w wolnym thumaczeniu ,nie na moim podwórku”), BANANA - „,build absolutely nothing anywhere near anything” 
badaniu podjęto próbę uchwycenia a priori tych różnic i sformułowano pytania w następujący sposób:

a) „Czy był(a)by Pan(i) gotowy(a) wziąć udział w konsultacjach w sprawie, która jest bezpośrednio dla Pana(i) ważna, nawet gdyby odbywało się to kosztem ważnych dla Pan(a/i) zajęć?",

b) „A czy był(a)by Pan(i) gotowy(a) wziąc udział w konsultacjach w sprawie, która Pana(i) bezpośrednio nie dotyczy, ale nie odbywałoby się to kosztem ważnych dla Pan(a/i) zajęć?”.

Fraza „nie odbywałoby się to kosztem ważnych dla Pan(a/i) zajęć” została dodana w pytaniu b ze względu na obawy o bardzo niski wskaźnik odpowiedzi pozytywnych, wzmacniany jeszcze wpływem tzw. oczekiwań ankietera (w tym przypadku respondent mógł domniemywać, że być może nie należy zajmować się sprawami, które go bezpośrednio nie dotyczą). Odpowiedzi pozytywne w pytaniu a uznano, nieuchronnie nieco upraszczając problem, za motywację tzw. egoistyczną do udziału w konsultacjach. Natomiast odpowiadających twierdząco na pytanie b uznano za przejawiających motywację wynikającą z troski o wspólnotę. Pamiętać należy, że były to odpowiedzi nierozłączne.

Jak wskazują wyniki w tabeli 4, najwyższa gotowość do udziału w konsultacjach motywowana troską o własne sprawy (egoistyczna) przejawiana jest przez mieszkańców Galicji (62\%) i zaboru rosyjskiego (63,9\%). Respondenci z byłego zaboru niemieckiego wyrażali ją w 49,3\%, zaś mieszkańcy ZZiP - 45,9\%. W skali kraju odpowiedzi twierdzących było nieco ponad połowa $(51,2 \%)$. W pytaniu tym proporcje między wyróżnionymi przez nas regionami nie odbiegają znacząco od wyników przedstawionych w tej tabeli (dla wszystkich form udziału ogółem).

W przypadku pytania b rozkład odpowiedzi ulega wyraźnemu zróżnicowaniu (tabela 5). Okazuje się, że cel wspólnotowy udziału w konsultacjach jest w Galicji przejawiany zdecydowanie częściej (51,2\% odpowiedzi twierdzących) niż w innych regionach. Dorównujący pod względem częstości gotowości udziału w konsultacjach mieszkańcy zaboru rosyjskiego w tym przypadku są mniej skorzy do deklaracji, gdyż tylko $31,3 \%$ z nich gotowych byłoby wziąć udział w konsultacjach, które ich bezpośrednio nie dotyczą. Podobny odsetek wskazań wystąpił wśród respondentów z ZZiP $(28,7 \%)$ i nieco mniejszy wśród mieszkańców zaboru niemieckiego - 25,8\%. Wśród ogółu badanych wyniósł on $30,8 \%$.

(w wolnym tłumaczeniu „nie budować absolutnie niczego w pobliżu czegokolwiek”) wyrażają anegdotycznie zgeneralizowaną postawę mieszkańców określonego miejsca, sprowadzającą się do negowania wszelkich inwestycji w ich otoczeniu lub otoczeniu ważnych zasobów publicznych. 

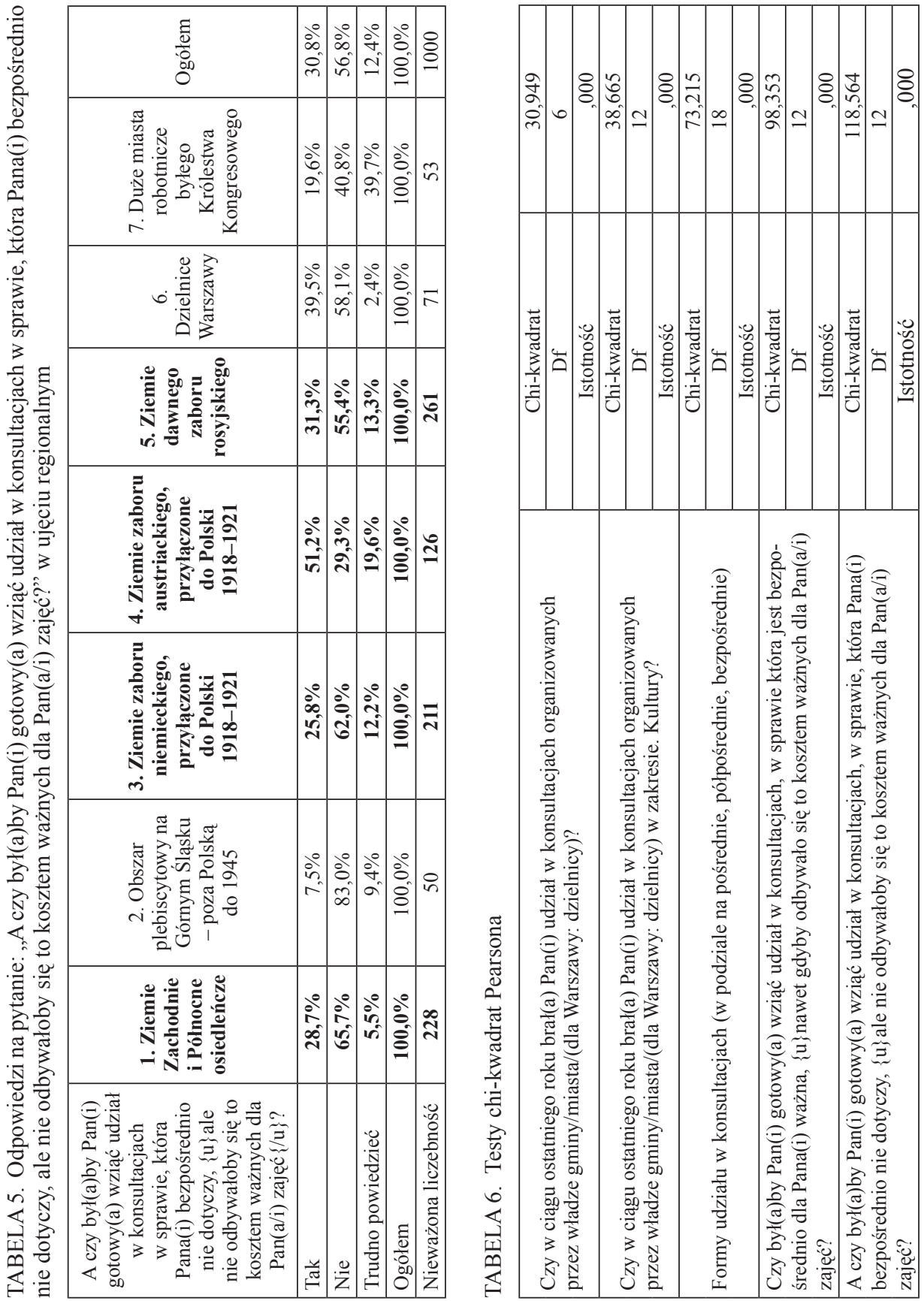

\begin{tabular}{|c|c|c|c|c|}
\hline 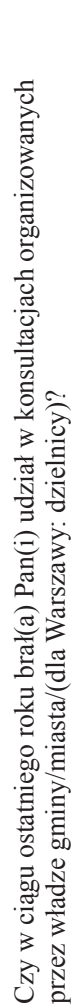 & 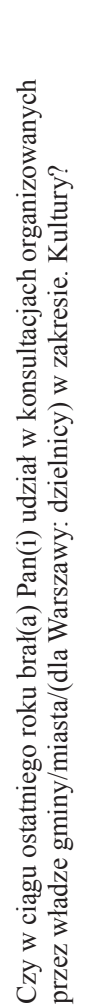 & 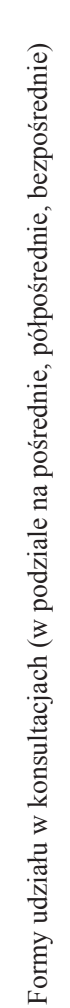 & 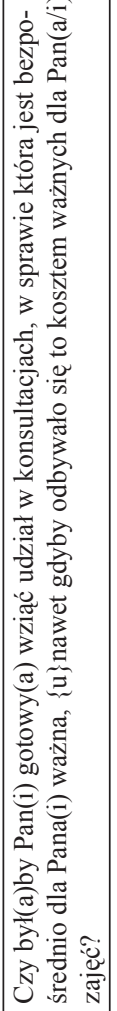 & 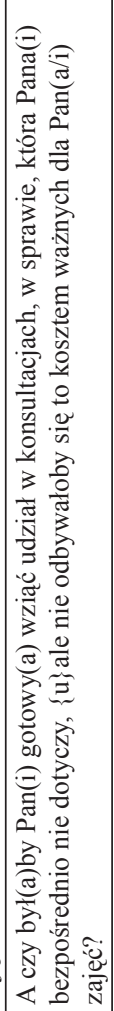 \\
\hline
\end{tabular}




\section{ZAKOŃCZENIE}

Za trwałością tezy o wpływie różnic pozaborowych na zachowania obywatelskie przemawia wciąż relatywnie wysoki odsetek ,zakorzenionych” Polaków. Według danych z ostatniego NSP 56,5\% Polaków mieszka w miejscowości, w której się urodziło. W małopolskim wskaźnik ten wynosił $62,8 \%$, zaś w podkarpackim - 61\%; obok łódzkiego (63,3\%) i świętokrzyskiego $(60,9 \%)$ były to najbardziej ,zasiedziałe” województwa. Najmniejszy wskaźnik był zaś w województwach zachodnich i północnych - około 50\% [Migracje wewnętrzne 2014: 30].

Trwałość wzorów kulturowych zachowań obywatelskich wynikać może również z przyjmowania ich także przez migrantów z innych regionów czy z obszarów wiejskich (jako atrakcyjnych i funkcjonalnych), o czym świadczy analiza Norberta Eliasa, który na przykładzie niewielkiego osiedla opisywał mechanizm utrzymywania się dominacji zachowań i wzorów kulturowych mieszkańców osiadłych względem świeżo osiedlających się [Elias 1994]. Poza wpływem bezpośrednim (w formie przekazu kulturowego) na kształtowanie postaw obywatelskich może oddziaływać trwałość powstałego w okresie zaborów zróżnicowania infrastruktury, układu przestrzennego, struktury wytwórczości etc. Na trwanie tych podziałów zdaje się wskazywać także efektywność działania samorządów, np. w zakresie pozyskiwania środków z UE.

$\mathrm{Z}$ drugiej strony, dochodzi do powolnego zacierania się różnic „międzyzaborowych". Po wojnie miała miejsce systematyczna migracja ludności ze wsi do miast, czasami transregionalna, powodując tzw. schłopienie miast.

Generalnie jednak galicyjski „fenomen” opisywany przez Jerzego Bartkowskiego i innych autorów wciąż wykazuje siłę oddziaływania. Wyraźnie wyższe są tu wskaźniki udziału w konsultacjach w przeszłości i zamiaru udziału w przyszłości.

Eksterminacja na szeroką skalę inteligencji - kształtującej często zachowania obywatelskie - w zachodniej Polsce i na Pomorzu podczas ostatniej wojny spowodowała osłabienie etosu, co zdają się potwierdzać przedstawione powyżej wyniki, zgodnie z którymi mieszkańcy tych regionów wykazują słabsze postawy obywatelskie, niż wynikałoby to z ich dziedzictwa kulturowego, ukształtowanego pod panowaniem pruskim i w zorganizowanym oporze przeciw niemu.

Wskaźniki dla ZZiP są konsekwentnie niższe. Potwierdzają to przeważające wnioski badaczy dotyczące tych terenów, których mieszkańców charakteryzują relatywnie rzadkie postawy obywatelskie.

Mieszkańcy zaboru rosyjskiego relatywnie rzadziej brali udział w konsultacjach, jednak zamiar udziału w nich w przyszłości, nawet w formie bezpośredniej, jest dość wysoki. Jeżeli jednak porównamy gotowość do poświęcenia swojego 
wolnego czasu na rzecz konsultacji społecznych, nawet w sprawach, które respondentów bezpośrednio nie dotyczą (patrz: ostatnie z omawianych pytań), to mieszkańcy Galicji znów najczęściej spośród wszystkich badanych wykazują taki zamiar, co przemawiałoby za trwałym zakorzenieniem kultury obywatelskiej w tym regionie.

\section{BIBLIOGRAFIA}

Banfield Edward. 1967. The moral basis of a backward society. New York: Free Press.

Bartkowski Jerzy. 2003. Tradycja i polityka. Wptyw tradycji kulturowych polskich regionów na wspólczesne zachowania społeczne. Warszawa: Żak

Berger Peter, Thomas Luckmann. 2010. Społeczne tworzenie rzeczywistości. Warszawa: Wyd. PWN.

Elias Norbert, John L. Scotson. 1994. The established and the outsiders. London: Sage Publications.

Gorzelak Grzegorz, Jałowiecki Bogdan. 1998. „Koniunktura gospodarcza i mobilizacja społeczna w gminach w latach 1995-1997”. Studia regionalne i lokalne 25(58): 11-57.

Grosfeld Irena, Ekaterina Zhuravskaya. 2015. „Cultural vs. economic legacies of empires: evidence from the partition of Poland". Journal of Comparative Economics 43: 55-75.

Grzybowski Konstanty. 1959. Galicja 1848-1914 - historia ustroju politycznego na tle historii ustroju politycznego Austrii. Wrocław: Zakład Narodowy im. Ossolińskich, Wydawnictwo PAN.

Jasiewicz Krzysztof. 2009. „'The past is never dead': Identity, class, and voting behavior in contemporary Poland". East European Politics and Societies 23(4): 491-508.

Kaźmierczak Tomasz. 2011. Partycypacja publiczna: pojęcie, ramy teoretyczne. W: Partycypacja publiczna; o uczestnictwie obywateli w życiu wspólnoty lokalnej, A. Olech (red.), 83-99. Warszawa: Instytut Spraw Publicznych.

Konsultacje. 2016. W: Poradnik. Ngo.pl: Portal Organizacji Pozarządowych. Poradnik.ngo.pl/ konsultacje [dostęp: 18.03.2016].

Kotnarowski Michal. 2012. Metodologia. W: Dyktat czy uczestnictwo? Diagnoza partycypacji publicznej w Polsce. Tom 1, A. Olech (red.), 11-22. Warszawa: Instytut Spraw Publicznych.

Ksiega polskiej spóldzielczości. 2004. Bogumiła Szymańska-Rac (red.). Warszawa: Krajowa Rada Spółdzielcza.

Migracje wewnętrzne 2002-2011. 2014. Warszawa: GUS.

Nietyksza Anna. 1986. Rozwój miast i aglomeracji miejsko-przemystowych w Królestwie Polskim 1865-1914. Warszawa: PWN.

Peisert Arkadiusz, Michał Kotnarowski. 2012. Tradycje obywatelskie polskich regionów a partycypacja obywatelska. W: Dyktat czy uczestnictwo? Diagnoza partycypacji publicznej w Polsce. Tom 1, A. Olech (red.), 250-273. Warszawa: Instytut Spraw Publicznych.

Peisert Arkadiusz, Piotr Matczak. 2012. Aktywność lokalnej wspólnoty politycznej a modele partycypacji. W: Dyktat czy uczestnictwo? Diagnoza partycypacji publicznej w Polsce. Tom 1, A. Olech (red.), 103-120. Warszawa: Instytut Spraw Publicznych.

Pollack Martin. 2011. Cesarz Ameryki: wielka ucieczka z Galicji. Wołowiec: Wyd. Czarne.

Putnam Robert D. 1995. Demokracja w działaniu: tradycje obywatelskie we wspótczesnych Włoszech. Kraków: „Znak”. Warszawa: Fundacja im. Stefana Batorego. 
Putnam Robert D. 2008. Samotna gra w kręgle: upadek i odrodzenie wspólnot lokalnych w Stanach Zjednoczonych. Warszawa: Wyd. Akademickie i Profesjonalne

Raciborski Jacek. 1997. Polskie wybory: zachowania wyborcze społeczeństwa polskiego w latach 1989-1995. Warszawa: „Scholar”.

Swaniewicz Pawel, Jan Herbst, Marta Lackowska, Adam Mielczarek. 2008. Szafarze darów europejskich. Kapitat społeczny a realizacja polityki regionalnej w polskich województwach. Warszawa: Wydawnictwo Naukowe „Scholar”.

Wnuk-Lipiński Edmund. 2005. Socjologia życia publicznego. Warszawa: Wydawnictwo Naukowe „Scholar”.

Tujdowski Marcin. 2008. Odrębność socjologiczna Ziem Zachodnich i Północnych. W: Samorząd pomocniczy jako czynnik pobudzający społeczeństwo obywatelskie na wsi, A. Sakson, P. Węgierkiewicz (red.). Konin: Krajowe Stowarzyszenie Sołtysów, Warszawa: Stowarzyszenie Fundamenty Silnego Państwa, Poznań: Instytut Zachodni.

Tych Feliks. 1990. Rok 1905. Warszawa: KAW.

Zarycki Tomasz. 1997. „Nowa przestrzeń społeczno-polityczna Polski”. Studia regionalne i lokalne 23(56) [cały numer].

Zarycki Tomasz. 2007. „History and regional development. A controversy over the 'right' interpretation of the role of history in the development of the Polish regions". Geoforum 38: 485-493.

Zarycki Tomasz. 2015. "Modernizacja kulturowa i polityczna jako ideologia inteligenckiej hegemonii”. Przeglad Socjologiczny 64 (2): 45-68.

Żukowski Ryszard. 2004. „Historical path dependence, institutional persistence, and transition to market economy. The case of Poland". International Journal of Social Economics 31(10): 955-973.

Arkadiusz Peisert

\title{
THE DIFFERENCES IN THE ATTITUDES TOWARDS SOCIAL CONSULTATIONS IN POLAND AS A MANIFESTATION OF THE REGIONAL DIFFERENTIATION OF CIVIC TRADITIONS
}

\begin{abstract}
This article presents the not new, but still fascinating, subject of the impact of regional differences in Poland on civic attitudes and behaviour. It is based on the assumption that the territories subject to the Prussian Partition, the Russian Partition or the Austrian Partition, respectively, of Poland in the 19th century still have very important differences in their civic traditions in today's Poland. The so called Northern and Western Territories incorporated into Poland after WWII (and formerly belonging to Prussia) are a separate issue and are discussed separately.

In the article, the main indicator of this differentation consists of the attitudes and behaviours with respect to social consultations. This article utilises outputs of the research into civic participation which was carried out within the framework of the programme "Let's decide together", financed by European Union and accessed thanks to the Foundation of the Public Affairs Institute in Warsaw.

Keywords: Partitions of Poland, social consultations, civic traditions, civic participation, social participation
\end{abstract}

